\title{
An Analysis of Figurative Language in Maroon 5 - Nobody's Love Song Lyrics
}

\author{
Farhan Muhammad ${ }^{1}$, Didin Nuruddin Hidayat ${ }^{2}$, Alek $^{3}$ \\ ${ }^{1,2,3}$ UIN Syarif Hidayatullah Jakarta \\ e-mail: ${ }^{1}$ farhan_muhammad19@mhs.uinjkt.ac.id, ${ }^{2}$ didin.nuruddin@uinjkt.ac.id, ${ }^{3}$ alek@uinjkt.ac.id

Diterima Direvisi Disetujui \\ 26-12-2020 01-03-2021 08-03-2021
}

\begin{abstract}
Beautiful words have special meanings and involve expressing ideas in song lyrics through figurative language. This study discussed an analysis of the figurative language in the Maroon 5 song's lyrics. This study emphasizes the use of figurative language and meaning in the lyrics of the song "Nobody's Love" by Maroon 5. Furthermore, the data source was taken from the lyrics of the Maroon 5 song lyrics. This research employed the descriptive qualitative model. In the analysis, the procedure began by reading the lyrics. Second, the researchers sought to identify words, phrases, and phrases that involved figurative language and catch each figurative language's context. Thirdly, the researchers took some notes about figurative language. Finally, the researchers classified and re-checked the details and analyzed them. The next step was the discussion of each category's results. The last step was drawing conclusions based on the report. The data showed five types of figurative language found in the lyrics of this song: Personification 20\%, Hyperbole 30\%, Irony 20\%, Simile $20 \%$, and Repetition $20 \%$.
\end{abstract}

Key Word: Figurative Language, Song, Lyrics

Abstrak - Kata-kata indah memiliki arti khusus dan melibatkan kemampuan mengungkapkan ide-ide dalam lirik lagu melalui bahasa kiasan. Penelitian ini membahas tentang analisis bahasa kiasan pada lirik lagu Maroon 5. Penelitian ini menekankan pada penggunaan bahasa kiasan dan makna dalam lirik lagu "Nobody's Love”, salah satu karya grup musik Maroon 5. Selanjutnya sumber data penelitian diambil dari lirik lirik lagu Maroon 5. Penelitian ini menggunakan model deskriptif kualitatif. Dalam tahap analisis, prosedur diawali dengan membaca lirik. Kedua, peneliti berupaya mengidentifikasi kata dan frasa yang melibatkan bahasa kiasan dan memahami isi konteks pada setiap bahasa kiasan. Ketiga, peneliti membuat catatan tentang bahasa kiasan. Kemudian, peneliti mengklasifikasikan dan mengecek ulang rincian dan menganalisisnya. Langkah selanjutnya adalah pembahasan hasil masing-masing kategori. Langkah terakhir yaitu menarik kesimpulan berdasarkan laporan tersebut. Studi ini menunjukkan bahwa ada lima jenis bahasa kiasan yang terdapat pada lirik lagu ini, yaitu: Personifikasi 20\%, Hiperbola 30\%, Ironi 20\%, Simile 20\%, dan Repetisi $20 \%$.

Kata kunci: Bahasa Kiasan, Lagu, Lirik

\section{INTRODUCTION}

One of the communication mechanisms used by humans is language. As a result, without words, humans would never be able to communicate with other beings. To share, support, discover, and provide useful ideas and knowledge for others, people need language. In literature, people use language, both spoken and written, in different ways.

People understand the shape of the language or its expression and its significance in studying and interpreting literary works. This means that they want the meaning found in them to be felt by readers or listeners and interpreted. However, it is often difficult for the reader to grasp the meaning of the utterance since the lyrics typically interpret it indirectly while constructing the meaning of the utterance used by the composer (Setiawati \& Maryani, 2018).

The song is one of the literary types. Most literary authors use it to express their thoughts, feelings, and emotions. A song grabs the attention of an audience and is usually composed by a talented composer and lyricist. Songs communicate several messages. Via songs, individuals can express their thoughts and feelings via sound to others. People can interact through songs with other individuals. In other words, as a means of communicating thoughts and feelings, the song should be used so that the audience can understand what the composer intended. 
Therefore, in the lyrics of the song, there is a secret message. Song lyrics use words that are less common in daily speech than those used. To construct their meaning, the lyrics use figurative language; if we can understand it, the meaning can sound deeper. He would have his view, even though the listener knows the meaning of the lyrics. Therefore, humans can perceive it without knowing the reality or conforming to the maker's intent with their interpretation. Beautiful words have precious meanings and involve the ability to express ideas in song lyrics through figurative language.

However, using figurative words is one way of interpreting the meaning of the expression and avoiding multiple interpretations. Figurative language is a type of language used by authors or speakers who articulate something outside Tarigan's literal sense (Azwardi, 2016). To research the implicit sense of language or expression in songs written by songwriters, these objectives can be felt and realized by readers or listeners.

The language that can not be taken literally (or can not only be taken literally) is figurative language. It utilizes words or phrases with meanings that are distinct from literal interpretations. In line with Defisyani et al. (2016), she claims that not only in writing but also in spoken language. In literary works, figurative language is often used, such as in articles in magazines, advertising, novels, and poetry (Siallagan et al., 2017).

In accordance, "Nobody's Love" is the first song of 2020 for the American pop-rock band Maroon 5 and serves as the second single for their next sixth studio album. This song was influenced lyrically by turbulent times in the world that were going at its release: the COVID-19 pandemic and demonstrations against Black Lives Matter. Adam Levine, the band singer, clarified the song's inspiration via an Instagram post and stated the purpose of the song was to give the listener love and hope about the difficult times. In this song, Adam Lavigne mostly uses figurative language in the lyrics of the song.

Based on the explanation above, it is important to analyze the use of figurative language in song lyrics. That is why the researcher wants to examine figurative language more thoroughly, especially in the song "Nobody's Love" by Maroon 5. Therefore, this research will concentrate on the figurative language and the context of song lyrics..

\section{Figurative Language}

Figurative words are one way of interpreting the meaning of the expression and avoiding multiple interpretations. Figurative language is a type of language used by authors or speakers who articulate something outside Tarigan's literal sense. According to Kalandadze et al. (2018), he argues that by learning figurative language to modify the meaning of a word or idea by contrasting it with other things, figurative language can enhance social communication skills.

\section{Personification}

Personification is expressing something by comparing it with human behavior. In line with Tairako (2018), personification is a kind of figurative language style that describes inanimate objects as if they have human characteristics.

\section{Hyperbole}

Hyperbole is figurative language that aims to explain something but is done by exaggerating the original reality to increase the impression and influence of something being discussed (Burgers et al., 2016).

Hyperbole is often found in literary works to convey that the message conveyed feels more influential on the reader. Besides, this figurative language is also often used in daily communication to make a dramatic impression to attract others' attention.

\section{Irony}

In general, this figurative language states something by reversing the context of what occurred (Tarigan, 2013); it can also be said that this figure of speech is concealing or hiding its real meaning. The sense of irony is contrary to what is said; it is subtle, but it can also offer a crude declaration of sense; humor or contrary figures categorize this figurative language.

\section{Simile}

The simile is a figurative language that uses direct comparative words to express something else. According to Hidayati (2017), simile compares two different things, which usually do not go together. Simile usually uses conjunctions such as: as if and like.

\section{Repetition}

Repetition is the repetition in a practical sense of sounds, syllables, words, or other parts of a sentence deemed necessary to emphasize (Keraf, 2009). Repetition is part of an affirmative figure of action and is also used as a rhetorical weapon. It is possible to use repetition to display or even threaten humor or illustrate strength, mood, and picture (Liontas, 2018).

\section{Previous Related Studies}


Several studies have been conducted as the previous study. First, Dewi et al. (2020) examined figurative language in "Lose You to Love Me" song lyric. The researchers found that the song lyrics contain several kinds of figurative language. Further, Fitria (2018) examined several types of figurative language used in One Direction's album. She found that repetition is the most frequently used in the lyrics of the song. Another study came from Arditami (2017), who analyzed the use of figurative language in Katy Perry's song lyrics. She found that symbols were the most frequently used in the song lyrics.

This study has several gaps with the previous studies above. In most previous research, they only classified figurative language types in the song lyrics without analyzing the meaning of the song lyrics they studied. Furthermore, this study focused on analyzing the types of figurative language and the meaning of the lyrics of the song "Nobody's Love."

\section{RESEARCH METHOD}

The present study employed the qualitative method in order to examine more thoroughly and solve problems in this review. Data is the portion to be analyzed and be carried out using the qualitative descriptive method. Descriptive research concentrates on the exploration of "what is" through findings and descriptive data. Therefore, data sources would be taken from the song of Maroon 5 in this research.

The data collection method in this study used the library study. According to George (2008), library research requires identifying and locating sources that include objective information or personal/expert opinion on the research issue. The researchers collect data from several sources, i.e., journals, the internet, or other written sources.

The procedure began by reading the lyrics. Second, the researchers sought to identify words, phrases, and phrases that involved figurative language and caught each figurative language's context. Thirdly, the researchers took some notes about figurative language. Finally, the researchers classified and re-checked the details and analyzed them. The next step was the discussion of each category's results. The last step was drawing conclusions based on the report. Further, the research questions are: (1) What are the forms of figurative language in the lyrics of the song "Nobody's Love"? and (2) What is the meaning of figurative language found in the lyrics of the song "Nobody's Love"?

\section{FINDINGS AND DISCUSSIONS}

After analyzing the data from the song lyric of Ice Cream, there are at least five figurative language types, such as personification, hyperbole, irony, simile, and repetition. The complete figurative languages are displayed below.

Table 1. Types of figurative languages found in the lyrics of the song "Nobody's Love"

\begin{tabular}{|c|c|c|c|}
\hline No & $\begin{array}{l}\text { Figurative } \\
\text { Language }\end{array}$ & Lyrics & $\begin{array}{l}\text { Number of } \\
\text { Occurrences }\end{array}$ \\
\hline 1 & Personification & $\begin{array}{l}\text { "You could make } \\
\text { a grown man cry. } \\
\text { If you ever said } \\
\text { "Goodbye"," } \\
\text { "You could make } \\
\text { a grown man cry. } \\
\text { If you left my } \\
\text { side" }\end{array}$ & 2 \\
\hline 2 & Hyperbole & $\begin{array}{l}\text { "You're the only } \\
\text { hand in my back } \\
\text { pocket" } \\
\text { "Baby, you're the } \\
\text { key to my heart, } \\
\text { lock it" } \\
\text { "Heaven, hear } \\
\text { me cryin', } \\
\text { cryin'" }\end{array}$ & 3 \\
\hline 3 & Irony & $\begin{array}{l}\text { "If you ever left, } \\
\text { never unlock it" }\end{array}$ & 1 \\
\hline 4 & Simile & $\begin{array}{l}\text { "Lonely like an } \\
\text { island" } \\
\text { "Hit me like a } \\
\text { drug" }\end{array}$ & 2 \\
\hline \multirow[t]{2}{*}{5} & Repetition & $\begin{array}{l}\text { "Only yours, } \\
\text { only yours" } \\
\text { "Never let you } \\
\text { go, oh, why? } \\
\text { (Never let you } \\
\text { go, oh, why?)" }\end{array}$ & 2 \\
\hline & \multicolumn{2}{|c|}{ Total } & 10 \\
\hline
\end{tabular}

\section{Intro}

Line 1 "You can make a grown man cry. If you ever said, "Goodbye""

Line 2 "Never let you go, oh, why? (Never let you go, oh, why?)"

Line 3 "You can make a grown man cry. If you ever left my side"

In the intro, the lyrics belong to two figurative languages consisting of two personifications and repetition. Personification can be found in lines 1 and 3 . In lines one and three, it is clear that the lyrics describe human expression. Meanwhile, repetition can be found in lines 2 . In the first line, the sentence "You can make a grown man cry" If you ever said, "Goodbye," the sentence describes an adult man who feels sad when he is left by a woman he loves so much. The word "goodbye" 
in that sentence is also interpreted as a parting word. In this sentence, it is also a songwriter that indirectly tells a woman he loves not to say "Goodbye" because it can make a man's heart sad.

Furthermore, in the third line, the sentence is the same as the first line sentence. The sentence illustrates that a woman can make a man cry if she leaves him. This sentence can also be interpreted as a form of sadness for a man abandoned by his lover.

Besides that, repetition can be found in lines 2 and 3 . Repetition is the repetition in a practical sense of sounds, syllables, words, or other parts of a sentence deemed necessary to emphasize (Keraf, 2009). The sentences in the second and fourth lines, these sentences use the figurative language of repetition. On the repetition of the sentence, "Never let you go, oh, why? (Never let you go, oh, why?) "Maroon 5 emphasized that he wanted to ask all women why they left the man he loved. This sentence is also interpreted as a man who does not want his girlfriend to leave him.

\section{Verse 1}

Line 1 "You're the only hand in my back pocket."

Line 2 "Heaven, hear me cryin', cryin'”

Line 3 "Baby, you're the key to my heart, lock it. If you ever left, never unlock it."

Line 4 "Lonely like an island, island."

In verse 1 , several figurative languages were found, which are hyperbole, irony, and simile. Hyperbole is a figurative language that aims to explain something but is done by exaggerating the original reality to increase the impression and influence of something being discussed (Burgers et al., 2016). In the sentences in the first and third lines, the sentence uses hyperbole figurative language. In the first line, the songwriter seems to exaggerate the use of words in the song lyrics. The word "hand" in the sentence "you're the only hand in my back pocket" indicates that here the songwriter wants to express that you (girlfriend) are the only woman in my heart. This sentence also aims to beautify the lyrics of the song to create an aesthetic impression.

Furthermore, the use of hyperbole is contained in the sentence on the third line. On the word "key" in the sentence "Baby, you are the key to my heart, lock it." the word "key" can be interpreted as a girlfriend. In this sentence, the songwriter looks like he wants to express to the woman he loves to lock his heart so that he does not turn to other people or cheat.

Besides, the use of irony is in the first and third lines. The irony is one of the figurative languages in which the speaker's intention varies from the phrase's context (Ali \& Hamdi, 2019). In the sentence "I'd go psychotic," the songwriter uses figurative irony language that serves as a satire. The sentence in this song can be interpreted as a man who does not want his girlfriend to leave him, and if that happens, he will go crazy. Furthermore, the use of the figurative language simile is found in the fourth line. In the phrase "lonely like an island," the songwriter describes his mood when he broke up with his girlfriend. He feels alone, like living on an uninhabited desert island.

\section{Verse 2}

Line 3 "Hit me like a drug, and I can't stop it"

In verse 2 , there is a figurative language simile used by the songwriter in the song lyrics. The simile is a figurative language that uses direct comparative words to express something else. Songwriters use similes to describe one incident with another. As in the third line of the lyrics. The songwriter describes a man who feels as hit as being addicted to drugs; he feels hit like a drug addiction that cannot be quickly released.

\section{Post-Chorus}

Line 1 "Only yours, only yours, not just anybody's"

Line 3 "Nobody, nobody’s love."

In the post-chorus, most of the lyrics in this section use figurative language repetition. There are two repetitions of figurative languages in this section, on the first and third lines. There is the word "only yours, only yours" in the sentence in the first line. The singer uses repetition to emphasize the word "only yours." The lyrics' meaning is that a man wants to convince his girlfriend that he is the only woman he loves.

Furthermore, in the third line, the word "nobody" in the sentence "nobody, nobody's love." These lyrics are a continuation of the previous lyrics. In the lyrics in the word "nobody," the songwriter uses the repetition of words to get good lyrics and emphasize the word. The songwriter wants to convey that there is not a single woman he loves except for his girlfriend.

Based on the findings above, the lyrics of Nobody's Love song have five figurative languages. They are irony hyperbole, hyperbole, repetition, and personification. The personification was contained in line one and line three intros. Personification is that of figurative expression, which implies the human capacity is provided to animate abstraction. Ko (2018) claims that personification is a language style in 
literary works that offers individual properties to inanimate artifacts or living beings that are not human, such as plants and animals. Thus, they behave like human beings (Ko, 2018; Padillah et al., 2016). In accordance, the lyric "you could make a grown man cry if you ever say" goodbye." In fact, most adult men are not easily sad about many things. However, this lyric describes the sadness of a man who does not want to be left by his girlfriend.

Furthermore, repetition was noticed in the intro in lines two and in the post-chorus in lines one and three. Repetition is one of the figurative languages that utilize repetition to convey the term or expression's affirmation as meaning and to enhance the impression of the statement on the listener (Harya, 2016). In line with this, several studies that studied figurative languages in song lyrics have identified a type of repetition. For example, Ibrahim et al. (2019) stated in their study that 11 percent of the figurative form of language is repetition in "endless love." Dewi et al. (2020) has identified one repetition type in Selena Gomez's lyric album. Suka and Jeremia (2019) have found two repetition types in the One Direction album's chosen lyric. In accordance with the lyric, "only yours, only yours." The lyrics use repetition in order to beautify and enhance the sentence. Maroon 5 repeated the lyric because he wanted to emphasize that his love is for his girlfriend and not for anyone else.

Besides, the hyperbole form was contained in verse 1 in lines one, two, and three. Several studies (Abbas, 2019; Wood, 2017; Yusuf \& Amelia, 2018) suggest that hyperbole is the most figurative language type frequently encountered in everyday life in song lyrics. For example, in verse one in line one, the lyric "You're the only hand in my back pocket" is a sentence that will never happen in this world. A woman is likened to a hand that is always in a man's back pocket. Here it is clear that the songwriters exaggerate to create an aesthetic impression for listeners. This sentence is interpreted as a woman who is kept safe like a wallet in a man's back pocket.

Besides that, the irony was also included in verse one in line one and line three. Hee et al. (2018) argue that irony is a kind of sentence that communicates subtle references. Figurative language, in Irony terminology, typically states something by reversing the sense of the intention that has taken place (Green, 2018; Hee et al., 2018). This type is categorized as satire or strife. In accordance with the lyric, "If you ever left, I'd go psychotic" means satire. Maroon 5 wants to convey his disappointment with the lyrics of the song. The songwriter was disappointed because his girlfriend abandoned him. $\mathrm{He}$ expressed it satirically through the word psychotic. Therefore, Maroon 5 brings these lyrics in the song to express through the song.
Moreover, the simile is a linkage language that contrasts two fundamentally distinct objects but which are perceived to have identical aspects; an overt analogy in this sort may be translated as implying something that is precisely comparable to terms that are parables (Nur \& Miranti, 2018). In accordance with the lyric "hit me like a drug" is part of the simile. The lyrics are categorized into similes because they create similarities between hit and drug.

Based on the discussion above, the use of figurative language in the song entitled "Nobody's Love" from Maroon 5 makes the song sound more romantic and fun to the audience. By using various figurative language styles, songwriters may articulate what the message needs to say (Ratna, 2017). The message is brief, but it has a profound meaning. So that audiences will appreciate a collection of words that have been written by the songwriter, in this situation, Maroon 5 shared his heart into a collection of words that made him album lyrics that anyone will love. Thus, Maroon 5 uses figurative words to embellish the music he makes. In his song, Maroon 5 tells the story of a man who really loves his girlfriend. In this song also Maroon 5 tells what possibilities might happen if his lover abandoned him.

\section{CONCLUSION}

The analysis examined the song lyrics "Nobody's Love" by Maroon 5. Based on the findings and discussion above, the researchers concluded that many kinds of figurative languages were included in the song lyrics. The data revealed five kinds of figurative language used in this song's lyrics: Personification $20 \%$, Hyperbole $30 \%$, Irony $20 \%$, Simile $20 \%$, and Repetition $20 \%$. Hyperbole is the dominant figurative language used in the lyrics of the song. The use of hyperbole often appears in this song because the songwriter wants to emphasize a word that he wants to convey to all listeners. Hyperbole also has other functions to make lyrics more beautiful and aesthetic impression.

Furthermore, in this song, Maroon 5 wants to convey and explain a feeling he experiences when he loves his girlfriend. Maroon 5 also wants to send a message to all women not to go out or break up with their boyfriends.

It is hoped that this research would be useful and helpful to researchers interested in literary study, particularly song lyrics. In Addition, data can also be used as a source for potential scholars who want to extend their text analysis and can help readers think objectively about discourse analysis. 


\section{REFERENCES}

Abbas, A. H. (2019). Super-hyperbolic man: Hyperbole as an ideological discourse strategy in Trump's speeches. International Journal for the Semiotics of Law, 32(1), 1-18. https://doi.org/10.1007/s11196-019-09621-8

Ali, A. H., \& Hamdi, H. Q. (2019). A pragmatic study of irony in some British and Iraqi TV comic shows. Journal of Language Studies, l(4),

$28-48$. https://doi.org/10.25130/lang.v1i4.43

Arditami, P. R. (2017). An analysis of figurative language found in Katy Perry's song entitled "firework." Lingua Scientia, 24(2), 45-58.

Azwardi, S. (2016). Analysis of figurative language used in some Coldplay's song lyrics. Ilmu pendidikan: Jurnal kajian teori dan praktik kependidikan, 45(1), 1-13.

Burgers, C., Konijn, E. A., \& Steen, G. J. (2016). Figurative framing: Shaping public discourse through metaphor, hyperbole, and irony. Communication Theory, 26(4), 410-430. https://doi.org/10.1111/comt.12096

Defisyani, W., Hamzah, \& Fitrawati. (2016). The use of figurative language found in product advertisements for different genders. $E$ Journal of English Language and Literature, 7(1), 253-265.

Dewi, E. N. F., Hidayat, D. N., \& Alek. (2020). Investigating figurative language in "Lose You to Love Me" song lyric. Loquen: English Studies Journal, 13(1), 6-16. https://doi.org/10.32678/loquen.v13i1.2548

Fitria, T. N. (2018). Figurative language used in one direction's album entitled up all night. ELITE Journal, 5(1), 69-79.

George, M. W. (2008). The elements of library research: What every student needs to know. Princeton University Press. https://doi.org/10.1515/9781400830411

Green, M. (2018). Irony as expression (of a sense of the absurd). The Baltic International Yearbook of Cognition, Logic and Communication, 12(1), 1-24. https://doi.org/10.4148/19443676.1116

Harya, T. D. (2016). An analysis of figurative languages used in Coelhos's novel entitled "alchemist." Premise Journal, 5(2), 45-63. https://doi.org/10.24127/pj.v5i2.815

Hee, C. Van, Levefer, E., \& Hoste, V. (2018).
Exploring the fine-grained analysis and automatic detection of irony on Twitter. Language Resources and Evaluation, 52(1), 707-731. https://doi.org/10.1007/s10579-0189414-2

Hidayati, N. (2017). Figurative language in Kakong community: A study in Lombok island. Journal of English Education, 2(1), 74-82.

Ibrahim, I., Akib, M., \& Hasyim, R. (2019). The analysis of figurative language in "endless love” song lyric. 8(2), 119-130. https://doi.org/10.33506/li.v8i2.464

Kalandadze, T., Norbury, C., Nærland, T., \& Næss, K. A. B. (2018). Figurative language comprehension in individuals with autism spectrum disorder: A meta-analytic review. Autism, 22(2), 99-117. https://doi.org/10.1177/1362361316668652

Keraf, G. (2009). Diksi dan gaya bahasa. PT Gramedia Pustaka Utama.

Ko, H.-C. (2018). The sustainability of teaching personification in language education: A qualitative analysis using Kwang-Chung Yu's free verse. Sustainability, 10(1), 1-23. https://doi.org/10.3390/su10103517

Liontas, J. I. (2018). Exploring figurative language across the curriculum. The TESOL Encyclopedia of English Language Teaching, $1-9$. https://doi.org/10.1002/9781118784235.eelt07 55

Nur, M. R. O., \& Miranti, R. R. (2018). The analysis of figurative language used in 'still I rise' poem by Maya Angelou. International Summit on Science Technology and Humanity, 19-29.

Padillah, E. N., Firmawan, H., \& Purwaningsih, E. (2016). Simile, hyperbole, personification and metaphor used in Gayle Forman's if $i$ stay. 4(1), 69-78.

Ratna, A. P. (2017). An analysis of figurative language found in Katy Perry's song entitled "firework." Lingua Scientia, 24(2), 45-58. https://doi.org/10.23887/ls.v24i2.18799

Setiawati, W., \& Maryani. (2018). An analysis of figurative language in Taylor Swift's song lyrics. PROJECT (Professional Journal of English Education), 1(3), 261-268. https://doi.org/10.22460/project.v1i3.p261-268

Siallagan, S. R., Manurung, S., \& Sinaga, J. B. (2017). Analysis of figurative language and 
imagery in Taylor Swift's songs. ANGLO-

SAXON: Jurnal Ilmiah Program Studi Pendidikan Bahasa Inggris, 8(1), 55-67. https://doi.org/10.33373/anglo.v8i1.984

Suka, G., \& Jeremia, J. (2019). A description of figurative language found in selected lyrics of One Direction song. Universitas Sumatera Utara.

Tairako, T. (2018). Reification-thingification and alienation: Basic concepts of Marx 's critique of political economy and practical materialsm. Hitotsubashi Journal of Social Studies, 49(1), $1-28$.

Tarigan, H. G. (2013). Pengajaran gaya bahasa. CV Angkasa.

Wood, H. (2017). The politics of hyperbole on Geordie Shore: Class, gender, youth and excess. European Journal of Cultural Studies, 20(1),

$39-55$. https://doi.org/10.1177/1367549416640552

Yusuf, F., \& Amelia, A. R. (2018). Metaphor expression in fall for you song lyrics. ELITE Journal, 5(1), 35-45. https://doi.org/10.24252/elite.v5i1a4 